\title{
The work of coeditors: indispensable to the publishing of
} Gaceta

Francisco Espinosa-Larrañaga*

Gaceta Médica de México, Ciudad de México, Mexico

In December 2018, the National Academy of Medicine of Mexico published the book Academia Nacional de Medicina. Notas Históricas (National Academy of Medicine of Mexico. Historical notes), written by Martha Eugenia Rodríguez Pérez, PhD in history.

The reason for this communication is to comment that, in chapter 16 of said book, the Gaceta Médica de México editors are listed from 1864 to 2018. On page 111, in the 1993-1994 period, Dr. Héctor Pérez Rincón is mentioned as sole editor, omitting that doctors Alejandro Treviño Becerra and Pelayo Vilar Puig participated in the same period as co-editors.

It is important for co-editors to be mentioned, since editorial work is a teamwork that deserves recognition for those who have contributed to Gaceta Médica de México aggrandizement.
Gac Med Mex. 2019;155:307

Contents available at PubMed www.gacetamedicademexico.com 